\title{
Centropyxis aculeata (testate lobose amoebae) and associated diatoms from the intertrappean lacustrine sediments (Maastrichtian) of central India: Implications in understanding paleolake ecology
}

\author{
Bandana Samant, Arun Kumar, D. M. Mohabey, Sumedh Humane, \\ Deepesh Kumar, Anup Dhoble, and Priya Pizal
}

\begin{abstract}
The Deccan Continental Flood Basalt (DCFB) sequence of India includes the volcanic flows of the Deccan Traps and the intertrappean sedimentary lacustrine deposits that lie in between the flows. The well-preserved arcellinidan taxon Centropyxis aculeata and associated diatoms on their tests are described for the first time in India from palaeolake sediments (Maastrichtian) of the Bagwanya Intertrappean sequence in Central India. Laminated shales and clays yielded diatoms, arcellinidans and sponge spicules, whereas other lithofacies composed mainly of black cherts yielded marker palynomorphs of Maastrichtian age. Diatoms isolated from the sediments include the poorly preserved centric diatom Aulacoseira and other pennate diatoms. Sponge spicules are present in this microfossil assemblage and show similarity with the extant genus Corvospongilla.

Five diatom taxa, Cyclotella sp. (? meneghiniana); Pantocsekiella sp. (? ocellata); Achnanthes sp. (? brevipes); Diadesmis sp. (? confervacea); and Oricymba sp. (? tianmuensis), found associated with the tests of Centropyxis aculeata have been described. Palaeoecological interpretation of this palaeolake is based on the information derived from lithology, arecllinidans, diatoms and the palynomorphs. Bagwanya Palaeolake was a perennial, warm water, well oxygenated and very low salinity lake, surrounded by tropical to subtropical terrestrial and aquatic plants along its coast and also under shallow waters. The environment in this lake was under stress due to ongoing and extensive volcanism in the region, leading to $\mathrm{SO}_{2}$ and $\mathrm{CO}_{2}$ outgassing. Xenosomes of sand and various species of diatoms on the test of Centropyxis aculeata indicate that the shallow benthic environments of the lake had a sandy substrate.
\end{abstract}

Samant, Bandana, Kumar, Arun, Mohabey, D.M., Humane, Sumedh, Kumar, Deepesh, Dhoble, Anup, and Pizal, Priya. 2020. Centropyxis aculeata (testate lobose amoebae) and associated diatoms from the intertrappean lacustrine sediments (Maastrichtian) of central India: implications in understanding paleolake ecology. Palaeontologia Electronica, 23(3):a60. https://doi.org/10.26879/1082 palaeo-electronica.org/content/2020/3220-testate-lobose-amoebae 
Bandana Samant. Department of Geology, RTM Nagpur University, Nagpur-440001, India. bandanabhu@gmail.com

Arun Kumar. Department of Earth Science, Ottawa-Carleton Geoscience Centre, Carleton University, 1125

Colonel By Drive, Ottawa, ON K1S 5B6, Canada. arunkumarlko@hotmail.com

D.M. Mohabey. Department of Geology, RTM Nagpur University, Nagpur-440001, India.

dinomohabey@yahoo.com

Sumedh Humane. Department of Geology, RTM Nagpur University, Nagpur-440001, India.

sumedh.humane@gmail.com

Deepesh Kumar. Department of Geology, RTM Nagpur University, Nagpur-440001, India.

deepeshyadav003@gmail.com

Anup Dhoble. Department of Geology, RTM Nagpur University, Nagpur-440001, India.

anupdhobale@gmail.com

Priya Pizal. Department of Geology, RTM Nagpur University, Nagpur-440001, India.

priya.pisal1993@gmail.com

Keywords: deccan continental flood basalt (DCFB); intertrappean sediments; arcellinida; microfossils; palaeoecology

Submission: 22 March 2020. Acceptance: 14 November 2020.

\section{INTRODUCTION}

The Deccan Continental Flood Basalt (DCFB) sequences of India covers parts of central, western and southern India that include the Deccan Traps and the associated intertrappean beds (Figure 1). A significant part of the DCFB lies under the Arabian Sea. Mumbai Offshore Basin, a major petroliferous region in the Arabian Sea, has an almost complete Cenozoic sedimentary section that overlies the DCFB and Deccan Trap Breccia (Chatterjee et al., 2006).

The DCFB province of India is amongst the best-studied continental flood basalt provinces in the world. It covers an area of over $500,000 \mathrm{~km}^{2}$, with eruptive volumes estimated at $\sim 1.3 \times 10^{6} \mathrm{~km}^{3}$ (Jay and Widdowson, 2008) between 69 and 62 Ma ago (Pande, 2002; Sheth and Pande, 2014). However, Chatterjee et al., (2006) stated that the outpouring of enormous continental flood basalts of the DCFB spread over not just central and western India but also the adjoining Seychelles microcontinent, covering more than $1,500,000 \mathrm{~km}^{2}$ that marked the close of the Cretaceous Period (Figure 2). According to Cox (1989), the Deccan volcanism was associated with rifting and rapid migration of the Indian plate over the Reunion Island hotspot (Figure 2) that consequently affected the composition of the sediments as well as biota (Tandon, 2002). Sediments that are associated with and positioned below the DCFB are called "infratrappean" while sediments that lie in between the flows and were deposited during breaks in volcanic activ- ity are called "intertrappean". These intertrappean sediments have yielded a variety of fossil assemblages (Kapgate, 2005; Bonde, 2008; Khosla and Verma, 2014; Smith et al., 2015; Mohabey and Samant, 2019), including dinosaurs (Mohabey and Samant, 2013) and palynomorphs (Samant and Mohabey, 2014). Stratigraphic resolution and the duration of the sedimentary units and flows in the Deccan volcanic province are constrained by magnetostratigraphy, Milankovitch stratigraphy and stable organic carbon isotope studies (Hansen et al., 2001, 2005; Verma and Khosla, 2019).

Globally, the Late Cretaceous was a warm period, possibly due to the release of $\mathrm{CO}_{2}$ and $\mathrm{SO}_{2}$ to the atmosphere from extensive volcanism (Self et al., 2008). During this period, India was positioned south of the Equator (Figure 3), and the climate of the region was tropical-semitropical and arid-semiarid (Ali and Aitchison, 2008). This climatic condition prevailed before the onset of volcanic activity in the region, as indicated by the presence of well-developed calcrete profiles in the infratrappean sediments of the Lameta Formation (Mohabey et al., 1993; Tandon et al., 1995; Tandon and Andrews, 2001). The onset of volcanic activity in India had different sites and sources of eruptions (Hansen et al., 2005; Kale et al., 2020) that changed the climate in geographically separated regions from humid (Samant et al., 2014; Thakre et al., 2017) to arid (Khadkikar et al., 1999; Keller et al., 2009). Recent studies of paleosol associated with Deccan volcanic flows suggest a wet subtropical environment with mild seasonality (Dzombak et 


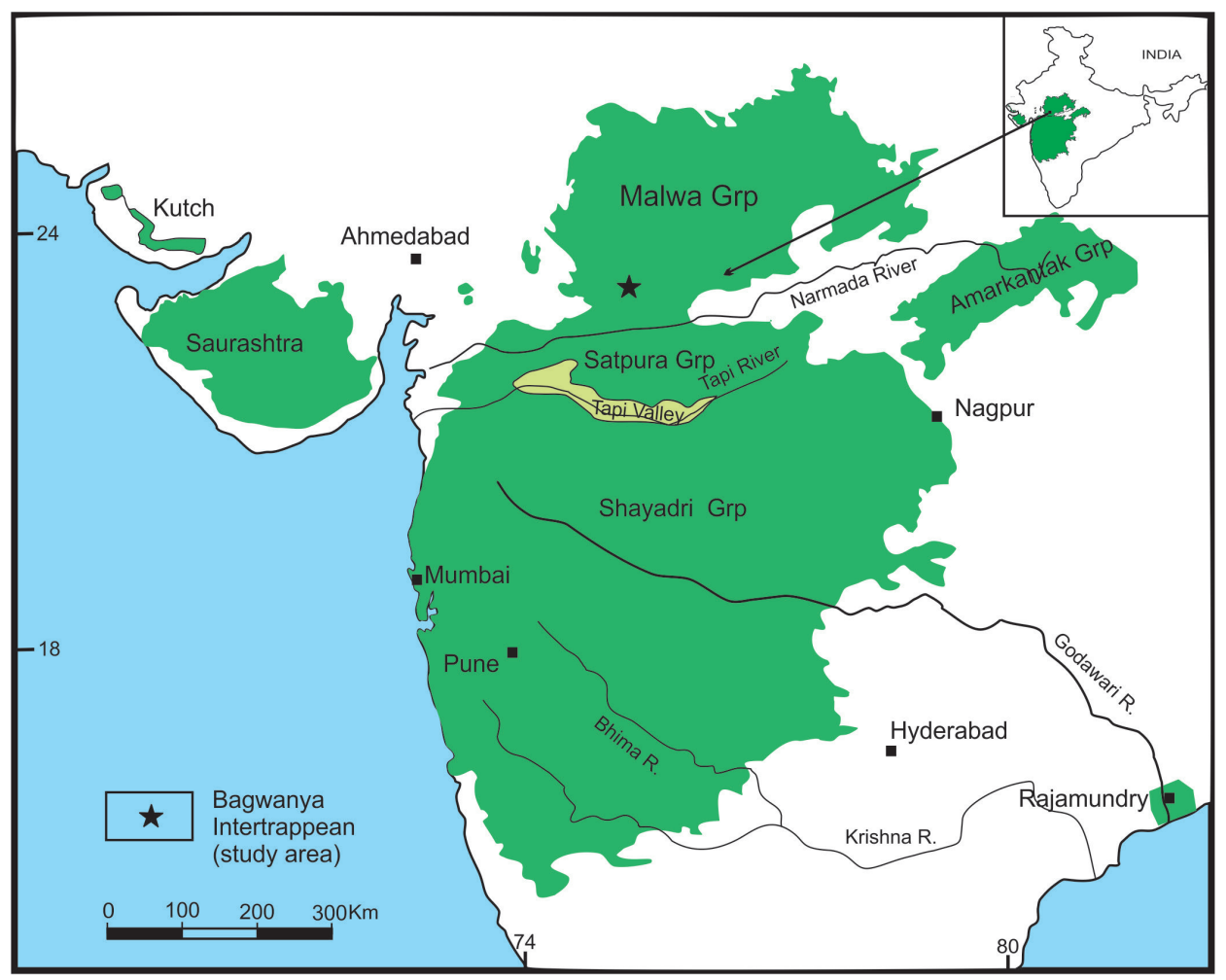

FIGURE 1. Map showing the central regions of India covered by the Malwa Group, and the location of the Bagwanya Intertrappean outcrops. Green areas are the extent of the Deccan Continental Flood Basalt (DCFB).

al., 2020). Evidence of such climatic and environmental changes are archived in the sediments and biota associated with the intertrappean sediments (Keller et al., 2009; Gertsch et al., 2011; Samant et al., 2014; Ghosh et al., 2006; Fantasia et al., 2016 and Thakre et al., 2017).

Arcellinidans are a group of shelled benthic protists commonly found in Quaternary lacustrine sediments. Their modern-day distribution is global, and they occur from the equator to the poles, in a variety of fresh to brackish aquatic and terrestrial habitats (Nasser and Patterson, 2015). They build their tests (microscopic shell) by agglutinating foreign particles (xenosomes) in an autogenous cement, usually mucopolysaccharides, thereby forming xenogenous tests. The nature of the xenosomes is entirely controlled by the composition of the substrate and may consist of sand grains and/ or diatom frustules (Medioli et al., 1990; Kumar and Patterson, 2000). Arcellinidans are sensitive to a wide range of environmental variables (Warner, 1990; Warner and Charman, 1994; Warner and Bunting, 1996; Charman et al., 2000; Patterson and Kumar, 2002; Patterson et al., 2002). Genus Centropyxis belongs to the Superfamily Arcellinina, commonly known as thecamoebians or testate lobose amoebae. The type species Centropyxis aculeata can be found in every lacustrine and most brackish environments; however, it prefers warmer waters above the thermocline. This species commonly occurs in Quaternary lacustrine sediments (Patterson and Kumar, 2002) but its geological record goes back to early Permian (Kumar et al., 2011).

Diatoms are unicellular, eukaryotic algae having siliceous cell walls and yellow-brown pigments (Battarbee et al., 2001). They commonly occur in all aquatic habitats and soils (John, 2014). Their oldest geological record is from the early Jurassic (Rothpletz, 1900); however, they commonly occur from early Cretaceous and younger sediments (Harwood and Gersonde,1990). The oldest known non-marine diatom Aulacoseira was reported from the Late Cretaceous Lameta Formation and intertrappean beds (Mohabey, 2001; Ambwani et al., 2003). Many of these fossil diatom species have forms akin to the present-day extant taxa.

Malwa Group flora (Mohabey et al., 2018) and fauna (Mohabey and Samant, 2013, 2019) provided initial information of the Late Cretaceous biota of this region. The objective of the present study is to record microfossils from Bagwanya 


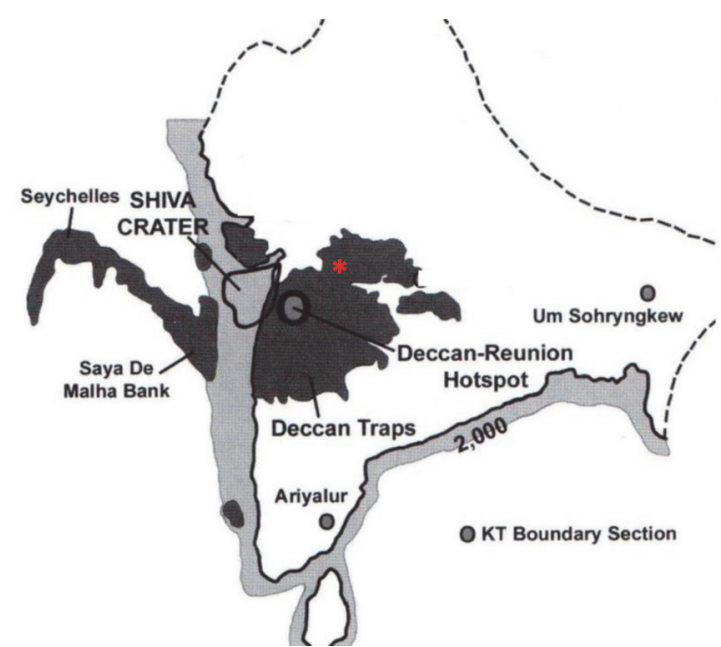

FIGURE 2. Palaeoposition of India - Seychelles during the Cretaceous - Tertiary transition (65 Ma ago), showing the geographical distribution of the Deccan Continental Flood Basalt (DCFB), commonly known as the Deccan Traps. Location of the Deccan-Reunion Hotspot is shown in relation to the geographic limits of the DCFB. The red asterisk marks the location of the Bagwanya Intertrappean outcrop (modified after Chatterjee et al., 2006).

Intertrappean (Maastrichtian) palaeolake sediments and evaluate the palaeoecological significance of the Arcellinidan assemblage and associated diatoms.

\section{GEOLOGY OF THE AREA}

The study area of the Bagwanya intertrappean lies in the Dhar district of Madhya Pradesh in Central India (Figure 1 and Figure 4). Deccan volcanic flows in the area are classified as the Malwa Group, having a cumulative thickness of $730 \mathrm{~m}$ that comprises 47 flows. The Malwa Group is divided into six formations, namely Mandleshwar, Kalisindh, Kankaria-Pirukheri, Indore, Bargonda and Singarchori formations in ascending stratigraphic order, and these flows are underlain by the Lameta Formation. Of these formations, only the lowermost Mandleshwar Formation, comprising seven basaltic flows, and the overlying Kalisindh Formation with its 11 basaltic flows, are associated with intertrappean paleolake sediments and red and green boles (Geological Survey of India, 1995). These boles are soiled or altered products of weathered basalt, and the red and green colour is due to the variable $\mathrm{Fe}_{2} \mathrm{O}_{3}$ and $\mathrm{MgO}$ content of these basaltic lava flows (Ghosh et al., 2006). Intertrappean beds occur at seven stratigraphic levels in the Mandleshwar Formation. The uppermost Ukala

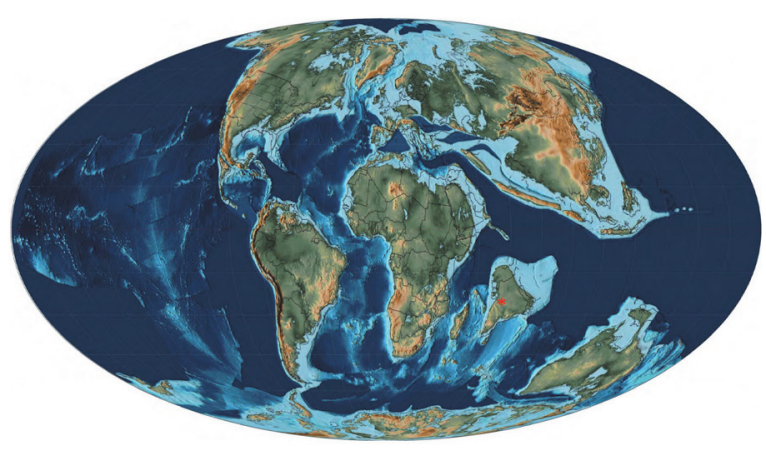

FIGURE 3. Palaeoposition of India during the Maastrichtian (68 Ma), showing its location south of the Equator. The red asterisk shows location of the Bagwanya Intertrappean outcrop (modified after Scotese, 2014).

intertrappean sediments in the Kalisindh Formation have bones of sauropod dinosaurs (Mohabey and Samant, 2013, Mohabey et al., 2019). Stratigraphically, the intertrappean palaeolake deposits of Bagwanya occur in the Mandleshwar Formation between the flows six and seven (Geological Survey of India, 1995, 2000, and unpublished reports; Mohabey et al., 2018; Figure 4).

Distinct facies variations are observed in the Bagwanya Palaeolake sediments that extend in an area of over $4 \mathrm{~km}^{2}$. The section having diatoms and arcellinidans is about $2.5 \mathrm{~m}$ thick (Figure 4), and comprises of about $80 \mathrm{~cm}$ of lumpy clays, 25 $\mathrm{cm}$ of laminated shales and clays, $100 \mathrm{~cm}$ of lumpy to laminated silty shales and $20 \mathrm{~cm}$ thick cherty limestone in ascending order. Shales and clays are rich in gastropods, ostracods, fish scales and teeth. The arcellinidans and diatoms are mostly recovered from the upper laminated lumpy silty shales (Figure 4). A magnetic polarity study carried out by us of the flows underlying and overlying this intertrappean section indicates normal polarity chron interpreted as Chron $30 \mathrm{~N}$ (Mohabey et al., 2018). The black to gray chert that is present in the eastern side of this palaeolake is rich in Maastrichtian angiosperm palynomorphs such as Azolla cretacea, Aquilapollenites bengalensis, Gabonisporis vigourouxii and Jiangsupollis sp. Apart from palynomorphs, the remains of vertebrates such as dinosaurs, crocodiles, fish and turtles are also recorded from this section. Based on the presence of marker Maastrichtian palynomorphs and the normal polarity of the underlying and overlying basaltic flows, the sediments are interpreted to have been deposited during Maastrichtian Chron $30 \mathrm{~N}$ of flows vis-a-vis the flows erupting in the same magnetic chron (Mohabey et al., 2018, 2019). Schöbel et al., 


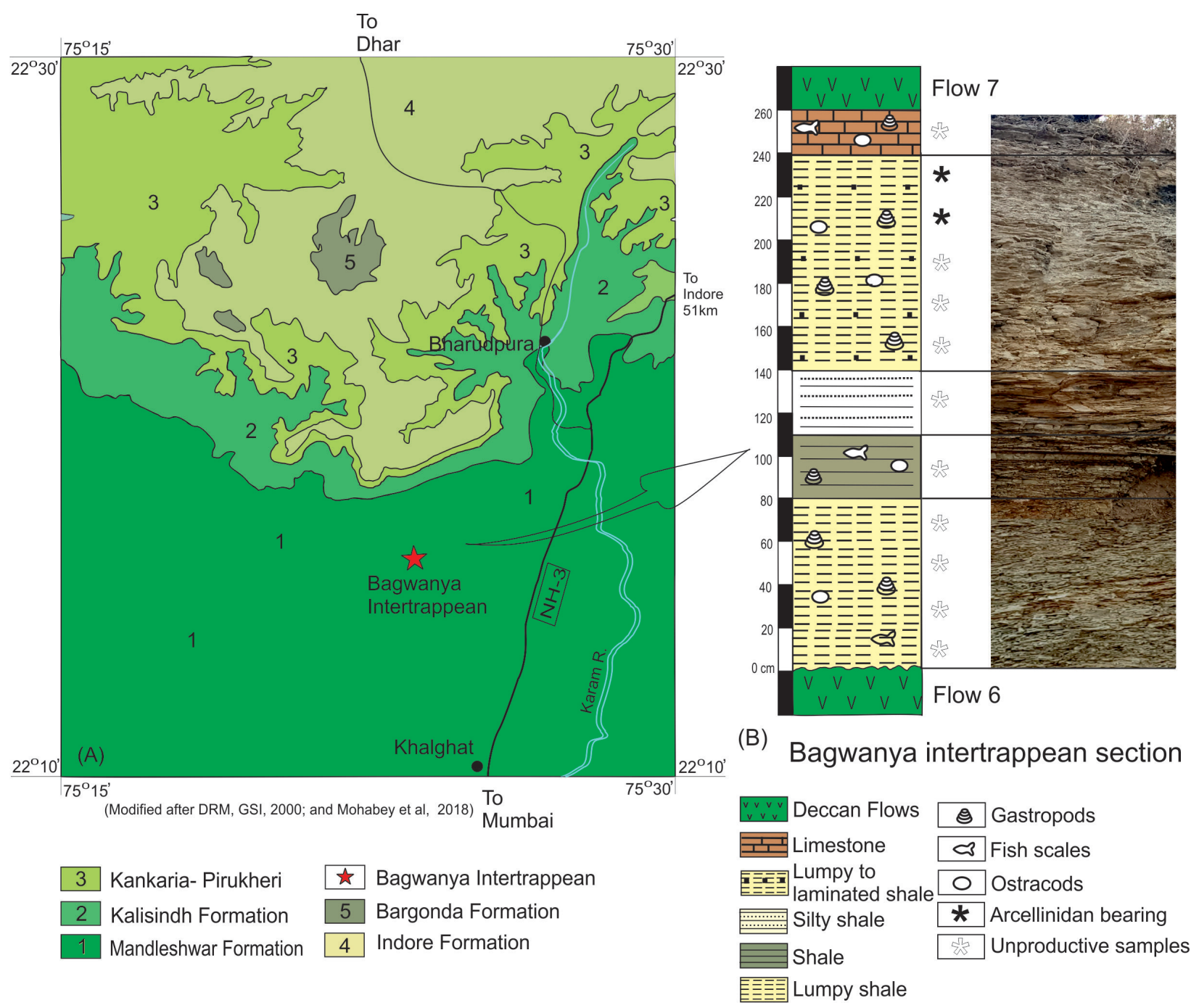

FIGURE 4. Location of the Bagwanya Intertrappean outcrop, showing lithostratigraphy of the section and corresponding lithology of the arcellinidan-bearing horizons.

(2014) suggested that the lower sequence of the lava flows of Malwa Group erupted during the

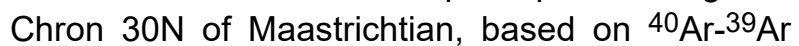
radioactive dating and magnetostratigraphy of the flows in the western part of the Malwa Group. One such flow having a normal magnetic polarity has yielded a ${ }^{40} \mathrm{Ar}-{ }^{39} \mathrm{Ar}$ age of $67.12 \pm 0.44$ (Schöbel et al., 2014).

\section{MATERIAL AND METHODS}

A total of 12 samples composed of shale, silty shale, laminated shale and limestone were macerated; out of these, only two samples yielded arcellinidans (Figure 4). Sample preparation and maceration techniques follow Traverse (1988) and Brasier (1980), with certain modifications. Briefly, about $50 \mathrm{gm}$ of each sample was thoroughly washed with distilled water, crushed into coarse sand size powder and treated with $5 \%$ hydrochloric acid $(\mathrm{HCl})$ to remove carbonates. This was followed by a treatment with $5 \%$ hydrofluoric acid (HF) for 15 minutes to remove silica, and $50 \%$ nitric acid and $5 \%$ potassium hydroxide $(\mathrm{KOH})$ for oxidation and the removal of humic matter. All the treatments were carried out at room temperature $\left(30^{\circ}\right.$ $35^{\circ} \mathrm{C}$ ). Residues were sieved through $15 \mu \mathrm{m}$ sieves and divided into two parts, one for the preparation of optical slides and the other for scanning electron microscopy (SEM). This size of the sieve used was to ensure that no arcellinidands or any other palynomorphs were lost. For optical slides, residues were mixed with a polyvinyl alcohol solution and smeared over a coverslip for drying. Later, coverslips were mounted on slides with Canada Balsam solution. Five slides were pre- 
pared from each sample. These slides were scanned under 200x magnification using an Olympus light microscope, model no. BX51 and photographs were taken at $400 x$ or $1000 x$ magnification with an Olympus light microscope, model no. BX 51 mounted with DP 20 camera. A total of 50 arcellinidans were counted from each sample and all of them were specimens of Centropyxis aculeata. Generally, each slide had five or more specimens of Centropyxis aculeata. This number was found to be adequate to observe morphological variations within this species.

For SEM, the technique for picking the desired grain was adopted from Ferguson et al., (2007). Briefly, the processed sample was mixed with glycerin, spread over a glass slide and scanned under the Zeiss light microscope, model Axio Imager using 100x magnification. The desired grain was picked with the help of human hair attached to a dissecting needle. The picked grain was mounted onto an SEM stub, and the grain was washed with alcohol to remove traces of glycerin. The prepared stubs were sputtered with gold-palladium and imaged with a JEOL JSM-IT300 Scanning Electron Microscope. SEM photographs were taken at an accelerating voltage of $15 \mathrm{kV}$ at the Jawaharlal Nehru Aluminum Research Development and Design Centre (JNARDDC) in Nagpur, India. All slides are stored at the museum of the Postgraduate Department of Geology, RTM Nagpur University, Nagpur.

The identification of Centropyxis aculeata is based on Ellison and Ogden (1987) and Kumar and Dalby (1998). Identifications of diatom taxa are based on Krammer and Lange-Bertalot (1986, 1988, 1991a, 1991b), John (2014) and Karthick et al., (2013).

\section{RESULTS}

In the studied intertrappean section, laminated to lumpy silty shale facies yielded arcellinidans (Figure 5), diatoms (Figure 6) and sponge spicules. However, cherts yielded only palynomorphs that include Azolla cretacea, Cyathidites australis, Gabonisporis vigourouxii, Aquilapollenites bengalensis, Jiangsupollis sp., Sparganiaceaepollenites sp. and Proxapertites spp. (Figure 7). The presence of Azolla cretacea, Gabonisporis vigourouxii, Aquilapollenites bengalensis and Jiangsupollis sp. suggests a Maastrichtian age (Samant et al., 2020).

The occurrence of Centropyxis aculeata and associated diatoms is reported for the first time from these intertrappean palaeolake sediments of
India. While Centropyxis aculeata shows distinct morphological details (Figure 5), the diatoms isolated from the sediments are poorly preserved and lack identifying morphological features. Broadly, the diatoms represent the centric genus Aulacoseira and indeterminate pennate diatoms. Their presence provides significant information about the paleoecology of this microfossil assemblage and the paleoenvironments of the intertrappean palaeolake.

\section{SYSTEMATIC PALAEONTOLOGY}

\section{Arcellinidans}

Arcellinidans, or testate lobose amoebae, are a group of protists that belong to the Order Arcellinida. Five or more specimens of arcellinidans represented only by Centropyxis aculeata were observed in each slide (Figure 5). Its morphology ranges from spiny to spineless. Their taxonomic position is as follows.

Phylum AMOEBOZOA (Lühe, 1913) Corliss, 1984

Subphylum LOBOSA Carpenter, 1861

Class TUBULINIEA Smirnov et al., 2005

Subclass TESTACEALOBOSIA De Saedeleer, 1934

Order ARCELLINIDA Kent, 1880

Suborder ARCELLININA Haeckel, 1884

Superfamily DIFFLUGACEA Stein, 1859

Family CENTROPYXIDAE Jung, 1942

Genus Centropyxis Stein, 1859 (ref. Patterson, R. T. and Kumar, A. 2002, Palaeo 3, 180:225-251)

Type Species. Centropyxis aculeata (Ehrenberg, 1832) (Figures 5, 6.1)

Description. Test bilaterally symmetrical, outline subcircular to ovoid; shell composed of proteinaceous matrix with agglutinated mineral grains and diatom frustules; aperture sub-terminal or eccentric, invaginated, with multiple spines (Ellison and Ogden, 1987). In the present assemblage, some spines are intact but many are often broken, vary between two to five or sometimes more, and test size varies between $60 \mu \mathrm{m}$ to $75 \mu \mathrm{m}$.

\section{Diatoms}

Many well-preserved frustules of pennate and centric diatoms were found attached on the Centropyxis aculeata tests. Diatoms could be identified only to the genus level because the central area, valve face or margins were often difficult to observe (Figure 6). Therefore, identification was assigned to the generic level, and species names are tentative and presented in parentheses with a question mark. The observed centric diatoms are 

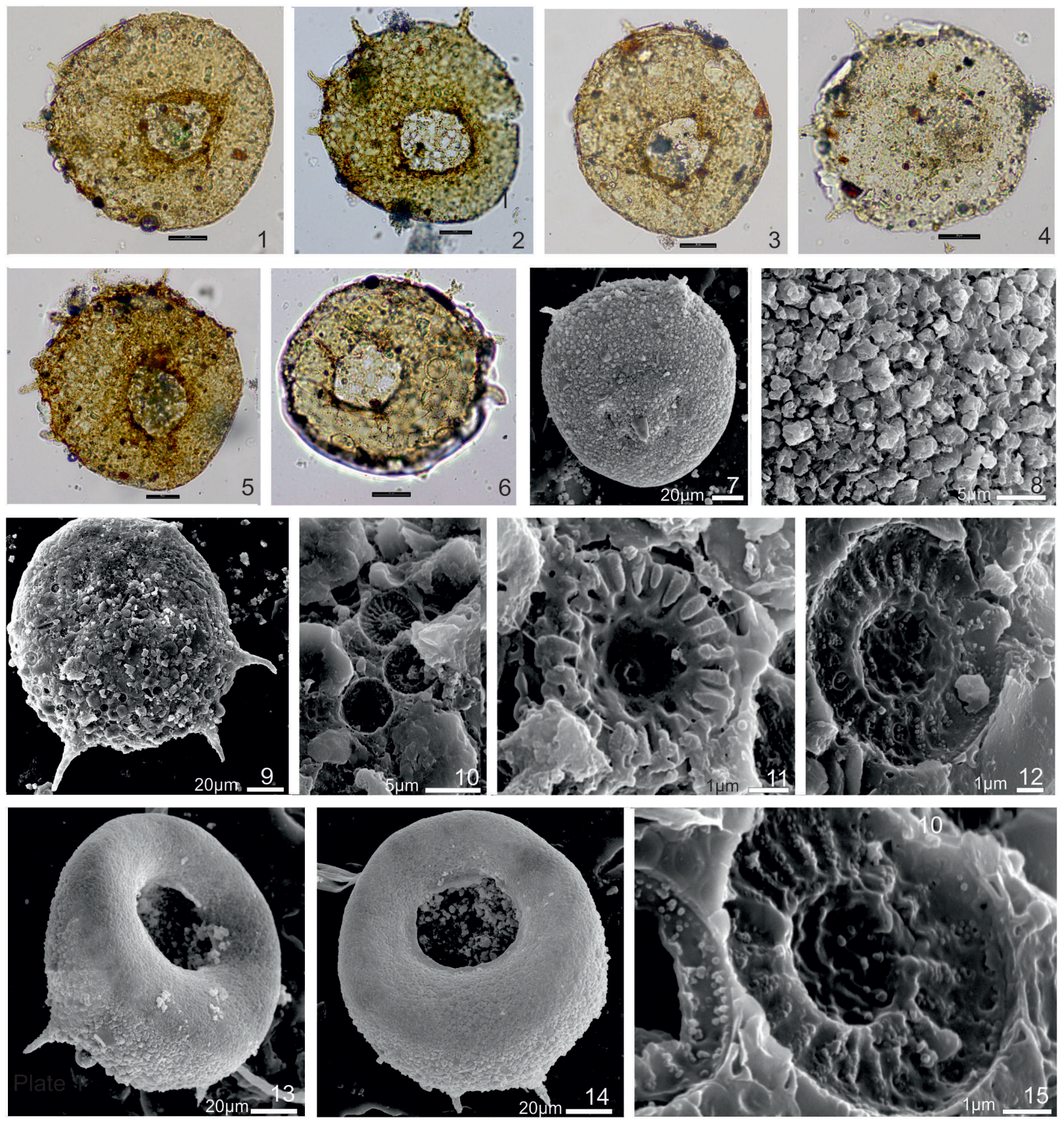

FIGURE 5. (Scale bar for figures $1-6$ is $10 \mu \mathrm{m}$; EF is England Finder Reading). 1-3. LM photograph of Centropyxis aculeata (Ehrenberg, 1832); 1. Slide no. 1A6, EF H48; 2. 1A3, EF K 40/2; 3. 1A4, EF K40/3. 4. LM photograph of Centropyxis aculeata (Ehrenberg, 1832) with big xenosomes of silica; Slide no 1A4, EF O61/2. 5-6. LM photograph of Centropyxis aculeata (Ehrenberg, 1832) showing presence of xenosomes of variety of diatoms as well as silica grains on the test; 5. Slide no 1A3, EF U38; 6. 1A1, EF E56/1. 7. SEM photograph of Centropyxis aculeata (Ehrenberg, 1832) showing presence of xenosomes of silica. 8. SEM showing magnified view of the same as 7. 9. SEM photograph of Centropyxis aculeata (Ehrenberg, 1832) showing presence of xenosomes of diatoms on the test. 10. SEM photograph of Centropyxis aculeata (Ehrenberg, 1832) showing presence of xenosomes of centric diatoms and silica grains on the test. 11-12 and 15 Centric diatom Cyclotella sp. on the test of Centropyxis aculeata (Ehrenberg, 1832). 13,14. SEM photographs of Centropyxis aculeata (Ehrenberg, 1832). 

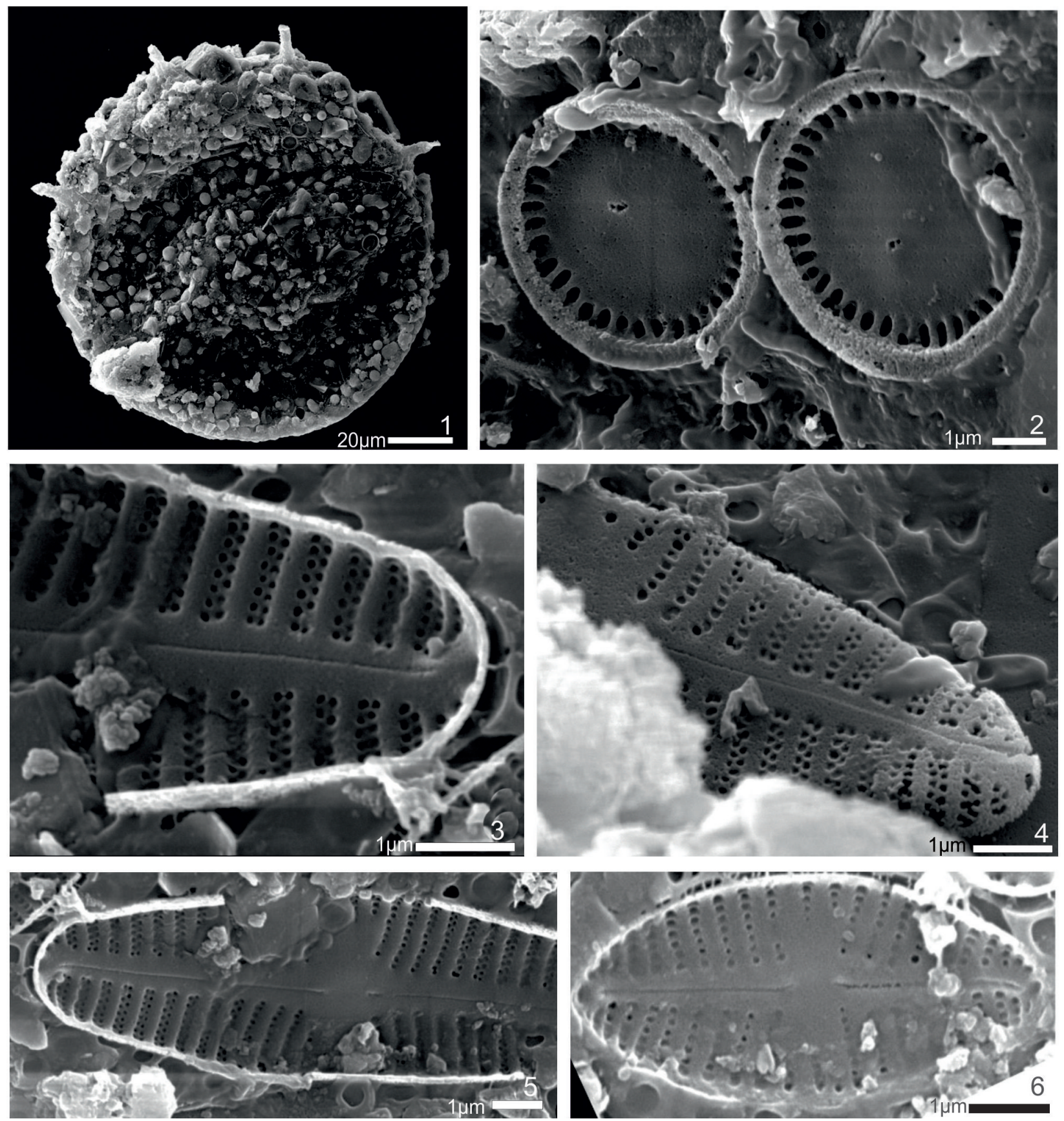

FIGURE 6. 1. SEM photograph of Centropyxis aculeata (Ehrenberg, 1832). 2. SEM photographs of the centric diatom Pantocsekiella sp. (internal valve view) on the test of Centropyxis aculeata (Ehrenberg, 1832). 3 and 5. SEM photographs of the pennate diatom Achnanthes sp. on the test of Centropyxis aculeata (Ehrenberg, 1832). 4. SEM photograph of the pennate diatom Oricymba sp. on the wall of Centropyxis aculeata (Ehrenberg, 1832). 6. SEM photograph of the pennate diatom Diadesmis sp. on the wall of Centropyxis aculeata (Ehrenberg, 1832).

Cyclotella sp., Aulacoseira sp., and Pantocsekiella sp.; pennate diatoms include Achnanthes sp. Diadesmis sp., and Oricymba sp.

Phylum BACILLARIOPHYTA Round et al., 1990 Subphylum COSCINODISCOPHYTINA Medlin and Kaczmarska, 2004

Class MEDIOPHYCEAE Medlin and Kaczmarska, 2004

Subclass THALASSIOSIROPHYCIDAE Round and Crawford, 1990

Order STEPHANODISCALES Nikolaev and 

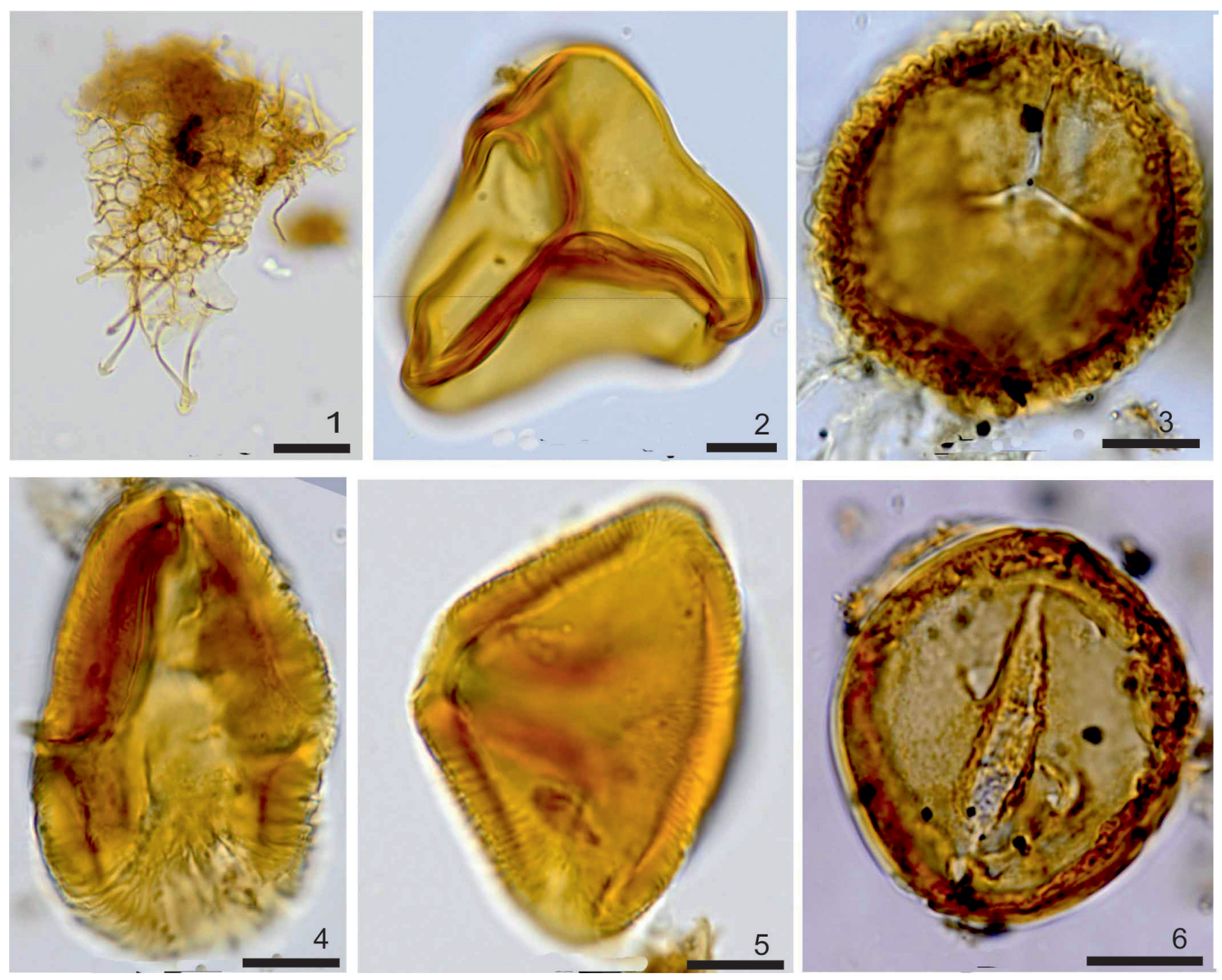

FIGURE 7. (Scale bar is $10 \mu \mathrm{m}$; EF is England Finder Reading). 1. Azolla cretacea Stanley, 1965; Slide no. BG2 S1; EF L55. 2. Cyathidites australis Couper, 1953 Slide no. BGVN L2; EF Q56. 3. Gabonisporis vigourouxii Boltenhagen, 1967; Slide no. BGVN E4; EF Q52. 4. Aquilapollenites bengalensis Baksi and Deb ex. Samant et al., 2013; Slide no. BGVN 1C6; EF N-34/1. 5. Jiangsupollis sp.; Slide no. BGVN L4, EF 45/1. 6. Proxapertites sulcatus Jaramillo et al., 2011; Slide no. BGVN E4, EF R31/1.

Harwood in Khursevich and Kociolek, 2012

Family STEPHANODISCACEAE Makarova in

Glezer and Makarova, 1986

Genus Cyclotella (Kutzing) Brebisson, 1838

Cyclotella sp. (? meneghiniana)

Figures 5.11-12 and 5.15

Description. Valve circular with tangential undulations. Radial striae in marginal zone are broader at margins and taper towards center; central region with one to three valve face fultoportulae. The fascicles are separated by inter-fasciular costae.

Dimensions. Valve diameter 4.5-5 $\mu \mathrm{m}$, diameter of central area $1.6-2.5 \mu \mathrm{m}$, striae $24-34$ in $10 \mu \mathrm{m}$, depression at the central area 2-3 $\mu \mathrm{m}$.

Genus Pantocsekiella Kiss and Ács in Ács et al., 2016

\section{Pantocsekiella sp. (? ocellata Kiss and Ács)} Figure 6.2

Description. Valves circular; internal surface view shows large circular foramen located at the junction between valve face and mantle; one slanting rimoportulae in the form of the lip like structure is present between the costae; at least one fultoportulae is present at the central area; striae are not visible in the internal surface view but costae are clearly seen. In between two costae, there may be one or two alveolate striae.

Dimensions. Valve diameter 5-5.2 $\mu \mathrm{m}$, diameter of central area 3.2-3.4 $\mu \mathrm{m}$, striae $25-30$ in $10 \mu \mathrm{m}$, costae 30 in $10 \mu \mathrm{m}$.

Class BACILLARIOPHYCEAE Haeckel, 1878

Subclass BACILLARIOPHYCIDAE Mann in

Round, Crawford and Mann, 1990 
Order COCCONEIDALES Cox, 2015

Family: ACHNANTHIDIACEAE Mann in Round, Crawford and Mann, 1990

Genus Achnanthes Bory de Saint-Vincent, 1822 Achnanthes sp. (? brevipes)

Figures 6-3 and 6-5

Description. Valve face weakly concave in the central area. Raphe is slightly curved, weakly deflected proximal ends and not extending in the central area. Apices show a moderate hyaline zone. Moderately radiating biseriate striae with rounded areolae. Internally striae are separated by thickened costae/virgae.

Dimensions. Length $12 \mu \mathrm{m}$, width 1.5-3.5 $\mu \mathrm{m}$, striae 24-26 in $10 \mu \mathrm{m}$.

Order NAVICULALES Bessey, 1907

Suborder NEIDIINEAE Mann in Kopalova et al., 2011

Family DIADESMIDACEAE Mann in Kopalova et al., 2011

Diadesmis sp. (? confervacea)

Figure 6.6 valve view

Description. Valves elliptical, central area broad and rounded, and tapered areal ends. Raphae is straight; the striae are radiate and punctate with variable length.

Dimensions. Length $11.4 \mu \mathrm{m}$; width $0.5-2.8 \mu \mathrm{m}$; striae 34 in $10 \mu \mathrm{m}$.

$$
\begin{gathered}
\text { Order CYMBELLALES Mann in Round, Crawford } \\
\text { and Mann, } 1990 \\
\text { Family CYMBELLACEAE Kützing, } 1844 \\
\text { Oricymba sp. (? tianmuensis) }
\end{gathered}
$$

Figure 6.4

Description. Valve shows uniseriate-biseriate striae. The distal raphe ends offset; bent slightly towards the dorsal margin. Striae show a strong tendency to become biseriate, circular, laterally elongate or irregular triangular areolae.

Dimensions. Length $12.5 \mu \mathrm{m}$, width $0.90-2.5 \mu \mathrm{m}$, striae 28-30 in 10 $\mu \mathrm{m}$.

\section{Sponge Spicules}

Sponge spicules are present in this microfossil assemblage as well, and they broadly show similarity with spicules of the extant genus Corvospongilla. A detailed study of sponge spicules recorded from these sediments is in progress.

\section{DISCUSSION}

The arcellinida bearing Bagwanya Intertrappean palaeolake rocks have yielded a monospecific assemblage of Centropyxis aculeata.
However, both centric and pennate diatoms associated with their tests show species diversity, with several taxa identified. This suggests that the paleoecology and lake chemistry were favorable only for the reproduction and survival of Centropyxis aculeata among Arcellinidans. Sediment lithology and the microfossils recovered are used to interpret palaeoecology of the Bagwanya Intertrappean palaeolake.

\section{Paleoenvironmental and Paleoecological Implications}

Bagwanya Intertrappean palaeolake is estimated to have covered an area of $4 \mathrm{~km}^{2}$. The time duration of this paleolake is unknown but the stratigraphic record of $2.6 \mathrm{~m}$ thickness of these lacustrine sediments suggests that Bagwanya paleolake lasted for at least several thousand years or more. We do not know if the shales with mm-thick laminations represent annual varves, so we do not attempt to determine the time duration of this $2.6 \mathrm{~m}$ section. Another $2.6 \mathrm{~m}$ thick intertrappean palaeolake shale deposit with similar mm-thick laminations, at Daiwal River section in central India, was estimated to have been deposited during a span of $100 \mathrm{ky}$. This time span was estimated using the presence of five maxima of Milankovitch cycles based on magnetic susceptibility of the sediments (Hansen et al., 1996). By analogy, we suggest that the Bagwanya Palaeolake sediments were deposited within a similar span of time as well. The climate of this region during Maastrichtian was tropical to subtropical as suggested by paleolatitude of central India at around $25^{\circ} \mathrm{S}$, as shown in Figure 3 (Lutgens and Tarbuck, 1996; Scotese, 2014).

Recent inter basaltic paleosol profile analysis suggests stable wet subtropical climate with slight seasonality in India during Masstrichtian (Dzombak et al., 2020). The following paleoecological discussion is based on sedimentological and microfossil observations of these intertrappean lacustrine sediments.

Sediments. These sediments are predominantly clay and shales, indicating deposition in relatively deeper and low energy environments. However, it is not possible to estimate the depth of this paleolake. Thin beds of chert and limestone are part of the sedimentary sequence as well. The presence of limestone as a chemical sedimentary rock in this stratigraphic sequence indicates that the lake water was clear and warm (between $30^{\circ} \mathrm{N}$ latitude and $30^{\circ} \mathrm{S}$ latitude) in which precipitation of calcium carbonate took place. The presence of chert beds 
indicates that the concentration of silica in the lake waters, during dry spells when $\mathrm{pH}$ becomes alkaline, may have exceeded 10. Another possible source of silica for the formation of chert may be biogenic silica derived from diatoms. Silica in the lake may have also been derived from the weathering of basaltic flows in the region. While the fine grained sediments, such as shale and clays, were deposited in the deeper parts of the lake, the shallower nearshore environments of the lake collected coarser sediments such as sand, as indicated by the presence of silica sand grains as xenosomes on Centropyxis aculeata tests (Figures 5 and 6).

Palynomorphs. The palynomorph assemblage of this intertrappean rock is dominated by the aquatic plant families Salviniaceae (Azolla cretacea), Marsileaceae (Gabonisporis vigourouxii) and Sparganiaceae/Typhaceae (Sparganiaceaepollenites). Modern Azolla is an aquatic fern and is sensitive to environmental parameters of aquatic ecosystems such as stagnant waters, ponds, ditches, canals or paddy fields. It prefers to grow in free-floating conditions (Kramer, 1990; Tryon and Tryon, 1982; Sadeghi et al., 2013) on calm water surfaces, and may thus be found on the surfaces of ponds, canals and lakes, as well as on some slow-moving rivers (Ghorbanzadeh and Tajer, 2009). Maximum plant density is obtained at a temperature range of $15^{\circ}-20^{\circ} \mathrm{C}$ and net primary productivity is highest within the $20^{\circ}-30^{\circ} \mathrm{C}$ of semitropical to tropical climate zones. Mean relative humidity for Azolla growth is estimated at 55-83\% (Lumpkin and Bartholomew, 1986). Family Salviniaceae strictly has floating aquatic plants, whereas Marsileaceae and Sparganiaceae have an amphibiously rooted habit.

The presence of modern epiphyllous fungi, mainly Microthyriaceae, is also significant for assessing palaeoclimate. The reproductive fruit bodies of these fungi are found abundantly in the contemporary mesophytic forests of tropical and subtropical climates. For their development, heavy rainfall rather than temperature is essential (Cookson, 1947; Dilcher, 1965; Selkirk, 1975). The common presence of epiphyllous fungi (Phragmothyries and Callimothallus) in the present samples suggests humid climatic conditions with good rainfall at the time of deposition during the Maastrichtian.

Arcellinidans. Arcellinidan assemblages have been correlated to a variety of environmental and climatic parameters; a review is provided by Patterson and Kumar (2000a, 2002). Arcellinidan response to environmental parameters such as metal and organic pollutant contamination (Kumar and Patterson, 2000; Patterson and Kumar, $2000 b)$, substrate type, salinity, levels of organics, oxygen concentration, water temperatures (Reinhardt et al., 1998; Farooqui et al., 2012) and water table fluctuations, humification, changes in intertidal flooding and land use change (Boudreau et al., 2005; Roe and Patterson, 2006) are among few of such studies. Centropyxis aculeata is an opportunistic species that is able to colonize environments that are unfavorable to other arcellinidan species, such as brackish environments (Scott and Medioli,1980; Boudreau et al., 2005; Farooqui et al., 2012), low-nutrient levels and oligotrophic conditions (McCarthy et al., 1995), and industrial and mining induced chemically contaminated sites (Reinhardt et al., 1998). Kerr (1984) cultured this species in bacteria-rich pond water devoid of algae and showed that Centropyxis aculeata is well suited to nutrient-poor environments. Similarly, McCarthy et al., (1995) found that Centropyxis aculeata probably feeds on bacteria. Generally, this species indicates various stressed environments including cold temperatures (Decloître,1956). Farooqui et al., (2012) demonstrated thecamoebian communities as proxies of seasonality in a lake in the Ganga-Yamuna Plains of North India in which the highest percentages of Centropyxis aculeata and its strains 'aculeata', 'discoides' and 'spinosa' occurred during the winter months when maximum temperatures are $\sim 25^{-0} \mathrm{C}$ and relative humidity is low.

In previous studies, arcellinidan tests attached with freshwater diatom frustules were recorded from Permian sediments in Himachal Pradesh and Godavari sub-basin, Andhra Pradesh, India (Farooqui et al., 2015). Arcellinidan taxa Centropyxis aculeata, Diffugia sp. A, and Lesquereusia spiralis have also been reported from the infratrappean Lameta Formation (Sonkusare et al., 2017). In the present study, we report the occurrence of Centropyxis aculeata and associated diatoms for the first time from the intertrappean palaeolake sediments of India.

The presence of Centropyxis aculeata in the intertrappean paleolake sediments is significant in two ways. Firstly, since pre-Quaternary geological occurrences of arcellinidans are sparse (Kumar et al., 2011), their presence in the Maastrichtian sediments of India demonstrates their longer geological history. Secondly, this species is widely known to be opportunistic, as evident from its occurrences in a wide range of environments described above; its presence in the intertrappean paleolake further demonstrates adaptability of this species to survive 
in diverse aquatic environments throughout its long geological history. This palaeolake likely suffered from a stressed environment due to constant volcanic activity and outgassing of $\mathrm{SO}_{2}$ and $\mathrm{CO}_{2}$ in which only Centropyxis aculeata could survive. Further work is required to investigate if other arcellinidan taxa inhabited this intertrappean palaeolake.

Diatoms. Diatoms attached to the Centropyxis aculeata tests are also good paleoecological indicators. Singh et al., (2006) have previously reported poorly preserved freshwater diatoms from the intertrappean sediments of India. The centric diatom Cyclotella suggests high $\mathrm{pH}$ (alkaline), fresh-water conditions. Cyclotella (meneghiniana?) commonly occurs in the modern eutrophic waters with low to high electrical conductivity and high alkalinity (Karthick et al., 2013). Similarly, the centric diatom Pantocsekiella (Cyclotella) indicates eutrophic lake conditions. Diatom assemblages with Pantocsekiella (Cyclotella) ocellata indicate meso-eutrophic, pelagic deep-water condition of lakes (Wang, 2012). Thus, the diatom assemblage associated with Pantocsekiella sp. in the present study suggests their deposition under meso-eutrophic, highly conductive electrolyte rich, pelagic environment of lakes. Diadesmis is a shallow water diatom found in lakes, marshes and ponds with high conductivity (Torgan and Santos, 2008). Thus, based on the resemblance of diatoms from the Bagwanya intertrappean paleolake to those found in modern lakes and other water bodies, it is surmised that the Maastrichtian sediments were deposited in a highly alkaline freshwater lake with mesotrophic to eutrophic waters. Extant sponges grow mostly in shallow water conditions.

Overall, in Bagwanya Palaeolake, the water is interpreted to be warm, well oxygenated and of very low salinity. The low salinity of the lake water is expected due to input from rain fall and streams and eroding sediments into the drainage basin of volcanic rocks. The sediment intake in the Bagwanya Palaeolake by perennial or seasonal streams probably impacted the salinity of the lake water. Since Bagwanya was a perennial paleolake, it promoted growth of tropical to subtropical aquatic plants along its coast and under its shallow waters. Recovered pollen and spores from these sediments support this observation. The common presence of phytoplankton such as diatoms in these sediments suggests that the lake was mesotrophic. These phytoplankton, along with arcellinidan taxon Centropyxis aculeata, ostracods, and higher vertebrates such as fish and crocodiles inhabiting this lake, were part of the food-chain within the lake. The presence of fossil teeth and bones of crocodiles suggest prevalence of tropical conditions during the deposition as well.

\section{CONCLUSIONS}

The arcellinidan Centropyxis aculeata and its associated diatoms from the Maastrichtian palaeolake sediments of the Bagwanya Intertrappean section from the Malwa Group, central India, are described in this study. Out of a total of 12 samples, only two produced thecamoebians. Lumpy to laminated silty shales in the paleolake beds yielded diatoms, arcellinidans and sponge spicules; other lithofacies, represented mainly by black cherts, yielded marker palynomorphs of Maastrichtian age. The well-preserved Centropyxis aculeata tests and their attached diatoms is reported for the first time from the intertrappean paleolake sediments of India. However, diatoms isolated from the sediments are poorly preserved centric diatom Aulacoseira and few pennate diatoms. Sponge spicules are present in this microfossil assemblage, which show similarity with extant genus Corvospongilla as well.

Five diatom taxa, Cyclotella sp. (? meneghiniana), Pantocsekiella sp. (? ocellata), Achnanthes sp. (? brevipes), Diadesmis sp. (? confervacea) and Oricymba sp. (? tianmuensis), were found associated with tests of Centropyxis aculeata. The presence of Centropyxis aculeata in these Maastrichtian sediments provides another pre-Quaternary example of its long geological history, extending to the Early Permian, as an opportunistic species found in diverse aquatic environments. On the basis of lithology and microfossils, Bagwanya Palaeoake is interpreted to be a perennial, warm water, well oxygenated, low salinity lake that provided ideal ecological conditions for the growth of tropical to subtropical terrestrial and aquatic plants along its coast and under shallow water conditions. Xenosomes of sand and different species of diatoms on the test of Centropyxis aculeata indicate that shallow benthic environments of the paleolake had a sandy substrate. Further work on sponge spicules and palynomorphs is in progress which will help in better understanding the ecological conditions of the intertrappean Late Cretaceous Bagwanya paleolake.

\section{ACKNOWLEDGEMENTS}

BS and DMM are thankful to the Ministry of Earth Sciences, New Delhi (Grant no. MoES/PO 
(Geosci)/49/2015) and University Grant Commission-SAP-II grant for financial assistance. We are also thankful to the Head, Department of Geology, RTM Nagpur University, Nagpur for providing working facilities. We thank the anonymous reviewers for their meticulous work, this paper has improved because of their comments. We also thank Mr. A.
Kumar of Ottawa, Canada, for linguistic improvements to the paper. We dedicate this research paper to the memory of A. Kumar's father, the late Mr. K.K. Srivastava of Lucknow, India, who was a student of Nagpur University and earned his M.A. degree in Economics in 1958.

\section{REFERENCES}

Ács, É., Ari, E., Duleba, M., Dressler, M., Genkal, S.I., Jakó É., Rimet, F., Ector, L. and Kiss, K.T. 2016. Pantocsekiella, a new centric diatom genus based on morphological and genetic studies. Fottea, 16(1):56-78. https://doi.org/10.5507/fot.2015.028

Ali, J.R. and Aitchison, J.C. 2008. Gondwana to Asia: Plate tectonics, paleogeography and the biological connectivity of the Indian sub-continent from the Middle Jurassic through latest Eocene (166-35 Ma). Earth-Science Reviews, 88:145-166. https://doi.org/10.1016/j.earscirev.2008.01.007

Ambwani, K., Sahni, A., Kar, R.K. and Dutta, D. 2003. Oldest known non-marine diatoms (Aulacoseira) from the uppermost Cretaceous Deccan Intertrappean beds and Lameta Formation of India. Revue de Micropaleontology, 46: 67-71. https://doi.org/10.1016/S0035-1598(03)00011-4

Battarbee, R., Jones, V., Flower, R., Cameron, N., Bennion, H., Carvalho, L., and Juggins, S. 2001. Diatoms, p. 82-115. In Smol, J.P., Birks H.J.B., Last, W.M., Bradley, R.S., and Alverson, K. (eds.), Tracking Environmental Change Using Lake Sediments, Terrestrial, Algal, and Siliceous Indicators. Springer, The Netherlands.

Bonde, S.D. 2008. Indian fossil monocotyledons: current status, recent development. sand future directions. The Palaeobotanist, 57:141-164.

Boudreau, R.E.A., Galloway, J., Patterson, R.E., Kumar, A. and Michel, F.A. 2005. A paleolimnological record of Holocene climate and environmental change in the Temagami region, northeastern Ontario. Journal of Paleolimnology, 33:445-461. https://doi.org/10.1007/s10933-004-7616-7

Brasier, M.D. 1980. Microfossils. George Allen and Unwin Ltd, London. https://doi.org/10.1002/ 9781118685440

Charman, D.J., Hendon, D., and Woodland, W. 2000. The identification of peatland testate amoebae. Quaternary Research Association Technical Guide 9, London.

Chatterjee, S., Guven, N., Yoshinobu, A., and Donofrio, R. 2006. Shiva Structure: A possible KT boundary impact crater on the western shelf of India. Special Publication 50, Museum of Texas Tech University, Lubbock, Texas.

Cookson, I.C. 1947. Fossil fungi from Tertiary deposits in the Sothern Hemisphere, Part 1. Proceedings of the Linnean Society, New South Wales, 72:207-214.

Cox, K.G. 1989. The role of mantle plumes in the development of continental drainage patterns. Nature, 342:873-877. https://doi.org/10.1038/342873a0

Decloître, L. 1956. Les thecamoebiens de l'Eqe (Groenland): Expeditions Polaires Francaises Missions Paul-Emile Victor VIII. Actualités Scientifiques et Industrielles Number 1242.

Dilcher, D.L. 1965. Epiphyllous fungi from Eocene deposits in western Tennessee, U.S.A. Palaeontographica (Abt.) B, 116:1-54.

Dzombak, R., Nathan, D.S., Mohabey, D.M., and Samant, B. 2020. Stable climate in India during Deccan volcanism suggests limited influence on K-Pg extinction. Gondwana Research, 85:19-31. https://doi.org/10.1016/j.gr.2020.04.007

Ellison, R. L. and Ogden, C. G. 1987. A guide to the study and identification of fossil testate amoebae in Quaternary lake sediments. Internationale Revue der gesamten Hydrobiologie und Hydrogeographie, 72:639-652. https://doi.org/10.1002/iroh.19870720509 
Fantasia, A., Adatte, T., Spangenberg, J. E., and Font, E. 2016. Palaeoenvironmental changes associated with Deccan volcanism, examples from terrestrial deposits from Central India. Palaeogeography, Palaeoclimatology, Palaeoecology, 441:165-180. https://doi.org/10.1016/j.palaeo.2015.06.032

Farooqui, A., Kumar, A., and Swindles, G.T. 2012. Thecamoebian communities as proxies of seasonalities in Lake Sadatal, in Ganga-Yamuna Plains of North India. Palaeontologia Electronica, 15(1)3A. https://doi.org/10.26879/200 https://palaeo-electronica.org/content/2012-issue-1-articles/117-thecamoebian-community

Farooqui, A., Aggrawal, N., Jha, N., and Phartiyal, B. 2015. Oldest record of freshwater diatom frustules in tests of Permian thecamoebians: faithfulness of sedimentary record. International Journal of Current Microbiological Applied Science, 4:472-485.

Ferguson, D.F., Zetter, R., and Paudayal, K.N. 2007. The need for the SEM in paleopalynology. Comptes Rendus Palevol, 6:423-430. https://doi.org/10.1016/j.crpv.2007.09.018

Geological Survey of India. 1995. Published Quadrangle Geological Map (QGM) of Indore, Madhya Pradesh. Map Printing Division, Geological Survey of India, Government of India Publications, Calcutta. (Scale: 1: 250,000).

Geological Survey of India. 2000. District Resource Map (DRM), Dhar District, Maharashtra. Map Printing Division, Geological Survey of India, Government of India Publications, Calcutta.

Gertsch, B., Keller, G., Adatte, T., Garg, R., Prasad, V., Berner, Z., and Fleitmann, D. 2011. Environmental effects of Deccan volcanism across the Cretaceous-Tertiary transition in Meghalaya, India. Earth and Planetary Science Letters, 310:272-285. https://doi.org/10.1016/j.epsl.2011.08.015

Ghorbanzadeh, M.S. and Tajer, M.G.P. 2009. Biotechnological potential of Azolla filiculoides for biosorption of $\mathrm{Cs}$ and Sr: Application of micro-PIXE for measurement of biosorption. Bioresource Technology, 100:1915-1921.

Ghosh, P., Sayeed, M.G.R., Islam, R., and Hundekari, S.M. 2006. Inter-basaltic clay (bole bed) horizons from Deccan traps of India: Implications for palaeo-weathering and palaeo-climate during Deccan volcanism. Palaeogeography, Palaeoclimatology, Palaeoecology, 242:90 109. https://doi.org/10.1016/j.palaeo.2006.05.018

Hansen, H.J., Toft, P., Mohabey, D.M., and Sarkar, A. 1996. Lameta age: dating the main pulse of Deccan Trap volcanism. Gondwana Geological Magazine, 2:365-374.

Hansen, H.J., Mohabey, D.M., and Toft, P. 2001. No K-T boundary at Anjar, Gujarat: evidence from magnetic susceptibility and carbon isotopes. Proceedings of the Indian Academy of Sciences, 11(92):1-10. https://doi.org/10.1007/BF02702213

Hansen, H.J., Mohabey, D.M., Lojen, S., Toft, P., and Sarkar, A. 2005. Orbital cycles and stable carbon isotopes of sediments associated with Deccan volcanic suite, India: Implications for the stratigraphic correlation and Cretaceous/Tertiary boundary. Gondwana Geological Magazine, 8:5-28.

Harwood, D.M. and Gersonde, R. 1990. Lower Cretaceous diatoms from ODP leg 113 site 693 (Weddell Sea). Part 2: resting spores, chrysophycean cysts, an endoskeletal dinoflagellate, and notes on the origin of diatoms, p. 403-125. In Barker, P.F., Kennett, J.P., O'Connell, S., Berkowitz, S., Bryant, W.R., Burckle, L.H., Egeberg, P.K., Fiitterer, D.K., Qersonde, R.E., Qolovchenko, X., Hamilton, N., Lawver, L., Lazarus, D.B., Lonsdale, M., Mohr, B., Nagao, T., Pereira, C.P.Q., Pudsey, C.J., Robert, C.M., Schandl, E., Spieß, V., Stott, L.D., Thomas, E., Thompson, K.F.M. and Wise Jr., S.W. (eds.), Proceedings of the Ocean Drilling Program, Science Results, 113. College Station, Texas.

Jay, A. and Widdowson, M. 2008. Stratigraphy, structure and volcanology of the SE Deccan continental flood basalt province: implications for eruptive extent and volumes. Journal of the Geological Society, 165:177-188. https://doi.org/10.1144/0016-76492006-062

John, J. 2014. An Introduction to Diatoms. International Workshop on Diatoms. Department of Geology, RTM Nagpur University, India.

Kale, V.S., Dole, G., Shandilyas, P., and Pande, K. 2020. Stratigraphy and correlations in Deccan Volcanic Province, India: Quo vadis? Geolological Society of America Bulletin, 132: 588-607. https://doi.org/10.1130/B35018.1

Kapgate, D.K. 2005. Megafloral analysis of intertrappean sediments with focus on diversity and abundance of flora of Mohgaonkalan, Mandla and adjoining areas of Madhya Pradesh. Gondwana Geological Magazine, 20: 31-45.

Karthick, B., Hamilton, P.B., and Kociolek, J.P. 2013. An illustrated guide to common diatoms of Peninsular India. Gubbi Labs, Bangalore, India. 
Keller, G., Adatte, T., Bajpai, S., Mohabey, D.M., Widdowson, M., Khosla, A., Sharma, R., Khosla, S.C., Gertsch, B., Fleitmann, D., and Sahni, A. 2009. KIT transition in Deccan Traps of central India marks major marine seaway across India. Earth and Planetary Science Letters, 282:10-23. https://doi.org/10.1016/j.epsl.2009.02.016

Kerr, H.A. 1984. Arcellaceans in Eastern Canada: selected biostratigraphic and biological studies. Unpublished Honours Thesis, Dalhousie University, Halifax, Nova Scotia, Canada.

Khadkikar, A.S., Sant, D.A., Gogte, V., and Karanth, R.V. 1999. The influence of Deccan volcanism on climates: Insights from lacustrine Intertrappean deposits, Anjar, western India. Palaeogeography, Palaeoclimatology, Palaeoecology, 147:141-149. https://doi.org/10.1016/S0031-0182(98)00156-4

Khosla, A. and Verma, O. 2014. Paleobiota from the Deccan volcano-sedimentary sequences of India: paleoenvironments, age and paleobiogeographic implications, Historical Biology, 27(7): 1-17. https://doi.org/10.1080/08912963.2014.912646

Kramer, K.U. 1990. Marsileaceae, p. 180-183. In Kubitzki, K. (ed.), The Families and Genera of Vascular Plants vol.1. Pteridophytes and Gymnosperms. Springer Verlag, Berlin.

Krammer, K. and Lange-Bertalot, H. 1986. Bacillariophyceae 1, Naviculaceae, p. 1-876. In Ettl, H., Gerloff, J., Heynig, H., and Mollenhauer, D. (eds.), Süsswasserflora von Mitteleuropa 2, T. 1. Fischer, Stuttgart.

Krammer, K. and Lange-Bertalot, H. 1988. Bacillariophyceae 2, Epithemiaceae, Bacillariacea, Surirellaceae, p. 1-596. In Ettl, H., Gerloff, J., Heynig, H., and Mollenhauer, D. (eds.), Süsswasserflora von Mitteleuropa 2, T. 2. Fischer, Stuttgart.

Krammer, K. and Lange-Bertalot, H. 1991a. Bacillariophyceae 3, Centrales, Fragilariaceae, Eunotiaceae, p. 1-576. In Ettl, H., Gerloff, J., Heynig H., and Mollenhauer, D. (eds.), Süsswasserflora von Mitteleuropa 2, T. 3. Fischer, Stuttgart.

Krammer, K. and Lange-Bertalot, H. 1991b. Bacillariophyceae 4, Achnanthaceae, p. 1-437. In Ettl, H., Gerloff, J., Heynig, H., and Mollenhauer, D. (eds.), Süsswasserflora von Mitteleuropa 2, T. 4. Fischer, Stuttgart.

Kumar, A. and Dalby, A.P. 1998. Identification key for Holocene lacustrine arcellacean (thecamoebian) taxa. Palaeontologia Electronica, 1.1.4A:1-35. https://doi.org/10.26879/98004

Kumar, A. and Patterson, R.T. 2000. Arcellaceans (Thecamoebians): New tools for monitoring long-and short-term changes in lake bottom acidity. Environmental Geology, 39:689-697. https://doi.org/10.1007/s002540050483

Kumar, A., Farooqui, A., and Jha, N. 2011.Early Permian glacio-marine thecamoebian assemblages from the northwest Himalayas, India. Journal of Micropalaeontology, 30:75-89. https://doi.org/10.1144/0262-821X10-021

Lumpkin, T.A. and Bartholomew, D.R. 1986. Predictive models for the growth response of eight Azolla accessions to climatic variables. Crop Science, 2:107-111. https://doi.org/10.2135/cropsci1986.0011183X002600010026x

Lutgens, F.K. and Tarbuck, E.J. 1996. Foundations of Earth Science. Prentice Hall, New Jersey.

McCarthy, F., Collins, E., McAndrews, J., Kerr, H., Scott, D.B., and Medioli, F. 1995. A comparison of postglacial arcellacean ("Thecamoebian") and pollen succession in atlantic Canada, illustrating the potential of arcellaceans for paleoclimatic reconstruction. Journal of Paleontology, 69:980-993. https://doi.org/10.1017/S0022336000035630

Medioli, F.S., Scott, D.B., Collins, E.S., and Wall, J.H. 1990. Fossil thecamoebians: present status and prospects for the future, p. 813-839. In Hemleben, C., Kaminski, M.A., Kuhnt, W., and Scott, D.B. (eds.), Proceedings of the NATO Advanced Study Institute on Paleoecology, biostratigraphy, paleoceanography and taxonomy of agglutinated foraminifera. NATO ASI Series C: Mathematical and Physical Sciences, 327. D. Reidel, Dordrecht.

Mohabey, D.M. 2001. Dinosaurs eggs and dung (fecal mass) from Late Cretaceous of central India: dietary implications. Geological Survey of India Special Publication, 64:605-615.

Mohabey, D.M. and Samant, B. 2013. Deccan continental flood basalt eruption terminated Indian dinosaurs before the Cretaceous-Paleogene boundary. Geological Society of India, Special Publication,1:260-267. https://doi.org/10.17491/cgsi/2013/63310

Mohabey, D.M. and Samant, B. 2019. Cretaceous-Paleogene transition of reptilian tetrapods across Deccan volcanism in India. Open Journal of Geology, 9:639-642. https://doi.org/10.4236/ojg.2019.910062 
Mohabey, D.M., Udhoji, S.G., and Verma, K.K. 1993. Palaeontological and sedimentological observations on non-marine Lameta Formation (Upper Cretaceous) of Maharashtra, India: their palaeoecologiclal and palaeoenvironmental significance. Palaeogeography, Palaeoclimatology, Palaeoecology, 105:83-94. https://doi.org/10.1016/0031-0182(93)90108-U

Mohabey, D.M., Samant, B., Dhobale, A., and Yadav D.K. 2018. Record of charcoal from early Maastrichtian intertrappean lake sediments of Bagh Valley, Madhya Pradesh: palaeofire proxy. Current Science, 114:1540-1544.

Mohabey, D.M., Samant, B., Dhobale, A., and Yadav, D.K. 2019. Reptilian vertebrates from Deccaan volcanic associated sediments of Malwa Plateau in context to reptiles across Cretaceous-Palaeogene volcanic eruptions in Main Deccan Volcanic Province, India. Global Geology, 22:250-257. https://doi.org/10.3969/j.issn.1673-9736.2019.04.03

Nasser, N.A. and Patterson, R.T. 2015. Conicocassis, a new genus of Arcellinina (testate lobose amoebae). Palaeontologia Electronica 18.3.46A:1-11. https://doi.org/10.26879/538

Pande, K. 2002. Age and duration of the Deccan Traps, India: A review of radiometric and paleomagnetic constraints. Proceedings of Indian Academy of Science (Earth and Planetary Science), 111:115-123. https://doi.org/10.1007/BF02981139

Patterson, R.T. and Kumar, A. 2000a. Use of Arcellacea (Thecamoebians) to gauge levels of contamination and remediation in industrially polluted lakes. p. 257-278. In Martin, R. (ed.), Environmental Micropaleontology. Plenum Press, New York.

Patterson, R.T. and Kumar, A. 2000b. Assessment of arcellacean (thecamoebian) assemblages, species and strains as contaminant indicators in variably contaminated James Lake, northeastern Ontario. Journal of Foraminiferal Research, 30:310-320. https://doi.org/10.2113/0300310

Patterson, R.T. and Kumar, A. 2002. A review of current testate rhizopod (thecamoebian) research in Canada. Palaeogeography, Palaeoclimatology, Palaeoecology, 180:225-251. https://doi.org/10.1016/S0031-0182(01)00430-8

Patterson, R.T., Dalby, A., Kumar, A., and Anderson, L., 2002. Arcellaceans (thecamoebians) as indicators of land use change: settlement history of the Swan Lake Area, Ontario as a case study. Journal of Paleolimnology, 28: 297-316. https://doi.org/10.1023/A:1021621622090

Reinhardt, E.G., Dalby, A., Kumar, A, and Patterson, R.T. 1998. Arcellaceans as pollution indicators in mine tailing contaminated lakes near Cobalt, Ontario, Canada. Micropaleontology, 44:131-148. https://doi.org/10.2307/1486066

Roe, H. and Patterson, R.T. 2006. Distribution of thecamoebians (testate amoebae) in small lakes and ponds, Barbados, West Indies. Journal of Foraminiferal Research, 36:116-134. https://doi.org/10.2113/36.2.116

Rothpletz, A. 1900. Über einen neuen jurassichen Hornschwamm und die darin eingeschlossenen Diatomeen. Zeitschrift der Deutschen Geologischen Gesellschaft, 52:154160.

Sadeghi, R., Zarkami, R., Sabetraftar, K., and Van Damme, P. 2013. A review of some ecological factors affecting the growth of Azolla spp. Caspian Journal of Environmental Science, 11(1):65-76.

Samant, B. and Mohabey, D.M. 2014. Deccan volcanic eruptions and their impact on flora: palynological evidence. Geological Society of America Special Paper, 505:171-191. https://doi.org/10.1130/2014.2505(08)

Samant, B., Mohabey, D.M., Srivastava, P., and Thakre, D. 2014. Palynology and clay mineralogy of the Deccan volcanic associated sediments of Saurashtra, Gujarat: age and paleoenvironments. Journal Earth System Science, 123:219-232. https://doi.org/10.1007/s12040-013-0390-z

Samant, B., Kapgate, D.K., Kumar, D., Mohabey, D.M., and Dhoble, A. 2020. Maastrichtian palynoflora from Deccan volcanic associated sediments of Mahurzari, Nagpur District, Maharashtra: age and paleoenvironment with comments on megaflora. Journal of Geological Society of India, 95:475-482. https://doi.org/10.1007/s12594-020-1464-6

Schöbel, S.H., De Wall, D., Ganerød, M., Pandit, M.K., and Rolf, C. 2014. Magnetostratigraphy and ${ }^{40} \mathrm{Ar}-{ }^{39} \mathrm{Ar}$ geochronology of the Malwa Plateau region (Northern Deccan Traps), central western India: Significance and correlation with main Deccan Large Igneous Province sequence. Journal of Asian Earth Sciences, 89:28-45.

https://doi.org/10.1016/j.jseaes.2014.03.022 
Scotese, C.R. 2014. Atlas of Late Cretaceous Maps, PALEOMAP Atlas for ArcGIS, volume 2, The Cretaceous, Maps 16 - 22, Mollweide Projection, PALEOMAP Project, Evanston, IL.

Scott, D.B. and Medioli, F.S. 1980. Quantitative studies of marsh foraminiferal distributions in Nova Scotia: implications for the sea level studies. Cushman Foundation for Foraminiferal Research, Special Publication Number 17.

Self, S., Blake, S., Sharma, K., Widdowson, M., and Sephton, S. 2008. Sulfur and chlorine in Late Cretaceous Deccan magmas and eruptive gas release. Science, 319:1654-1657. https://doi.org/10.1126/science. 1152830

Selkirk, D.R. 1975. Tertiary fossil fungi from Kiandra, New South Wales. Proceedings of the Linnean Society, New South Wales, 100:70-94.

Sheth, H.C. and Pande, K. 2014. Geological and ${ }^{40} \mathrm{Ar} / 39 \mathrm{Ar}$ age constraints on late-stage Deccan rhyolitic volcanism, inter-volcanic sedimentation, and the Panvel flexure from the Dongri area, Mumbai. Journal of Asian Earth Sciences, 84:167-175. https://doi.org/10.1016/j.jseaes.2013.08.003

Singh, R.S., Stoermer, E.F., and Kar, R. 2006. Earliest freshwater diatoms from the Deccan Intertrappean (Maastrichtian) sediments of India. Micropaleontology, 52:545-551. https://doi.org/10.2113/gsmicropal.52.6.545

Smith, S.Y., Manchester, S.R., Samant, B., Mohabey, D.M., Wheeler, E.A., Baas, P., Kapgate, D., Srivastava, R., and Sheldon, N.D. 2015. Integrating paleobotanical, paleosol, and stratigraphic data to study critical transitions: a case study from the Late CretaceousPaleocene of India, p. 137-166. In Polly, P.D., Head, J.J., and Fox, D.L. (eds.), Earth-Life Transitions: Paleobiology in the Context of Earth System Evolution. The Paleontological Society Papers 21. Yale Press, New Haven, CT.

Sonkusare, H., Samant, B., and Mohabey, D.M. 2017. Microflora from sauropod coprolites and associated sediments of Late Cretaceous (Maastrichtian) Lameta Formation of NandDongargaon Basin, Maharashtra. Journal Geological Society of India, 89:391-397. https://doi.org/10.1007/s12594-017-0620-0

Tandon, S.K., 2002. Record of the influence of Deccan volcanism on contemporary sedimentary environment in central India. Sedimentary Geology, 147:177-192. https://doi.org/10.1016/S0037-0738(01)00196-8

Tandon, S.K. and Andrews, J.E. 2001. Lithofacies associations and stable isotopes of palustrine and calcrite carbonate: examples from an Indian regolith. Sedimentology, 48:339-355. https://doi.org/10.1046/j.1365-3091.2001.00367.x

Tandon, S.K., Sood, A., Andrews, J.E., and Dennis, P.F. 1995. Paleoenvironment of the dinosaur-bearing Lameta Beds (Maastrichtian), Narmada Valley, central India. Palaeogeography, Paleoclimatology, Paleoecology, 117:153-148. https://doi.org/10.1016/ 0031-0182(94)00128-U

Thakre, D., Samant, B., Mohabey, D.M., Sangode, S., Srivastava, P., Kapgate, D.K., Mahajan, R., Upreti., N, and Manchester, S. 2017. A new insight into age and environments of intertrappean beds of Mohgaon Kalan, Chhindwara District, Madhya Pradesh using palynology, megaflora, magnetostratigraphy and clay mineralogy. Current Science, 112:2193-2197.

Torgan, L.C. and dos Santos, C.B. 2008. Diadesmisconfervacea (DiadesmiaceaeBacillariophyta): morfologia externa, distribuição e aspectosecológicos. Iheringia, Séries Botanica, Porto Alegre, 63(1):171-176.

Traverse, A. 1988. Paleopalynology, 1st edition. Unwin Hyman, London

Tryon, R. and Tryon, A.F. 1982. Ferns and Allied Plants. Springer, New York.

Verma, O. and Khosla, A. 2019. Developments in the stratigraphy of the Deccan Volcanic Province, peninsular India. Comptes Rendus - Geoscience, 351:461-476. https://doi.org/10.1016/j.crte.2019.10.002

Wang, Q. 2012. Environmental evolution of Lugu Lake, Yunnan and response to Southwest monsoon climate since LGM. Unpublished Ph.D. Thesis, Nanjing Institute of Geography and Limnology, Chinese Academy of Sciences, University of Nanjing, China.

Warner, B.G. 1990. Methods in Quaternary ecology, 5 Testate Amoebae (Protozoa). Geoscience Canada, 15:251-260.

Warner, B.G. and Bunting, M.J. 1996. Indicators of rapid environmental change in northern peatlands. p. 235-246. In Berger, A.R. and lams, W.J. (eds.), Geoindicators. Assessing Rapid Environmental Changes in Earth Systems. A.A. Balkema, Rotterdam. 
Warner, B.G. and Charman, D.J. 1994. Holocene changes on a peatland in northwestern Ontario interpreted from testate amoebae (Protozoa) analysis. Boreas, 23:270-279. https://doi.org/10.1111/j.1502-3885.1994.tb00949.x 